\title{
Animal Kingdoms: on habitat rights for wild animals
}

\author{
Steve Cooke
}

\section{Introduction}

Many philosophers have convincingly argued that non-human animals are worthy of direct moral concern for their own sakes and, further, that they are also rights-bearers. ${ }^{1}$ Rights protect certain interests and place constraints upon what may be done to an individual in the name of producing social or personal goods. ${ }^{2}$ In the case of humans, these protections and constraints are described by an extensive set of particular rights: rights to bodily integrity, personal and political freedoms, assistance and protection, rights to certain social and economic conditions, and so forth. For animals however, theorists have only recently begun to look beyond the most basic of animal rights, such as life, liberty, and bodily security. In order to move forward, animal rights theorists need to consider what these rights entail; whether non-human animals possess a richer more extensive set of rights; and what these rights demand of moral agents, particularly in cases of non-compliance. One such right that may be possessed by animals is a right to their habitat. Besides being killed for human consumption, one of the greatest threats to non-human animals comes from the loss of their habitats. When humans threaten the habitats of wild animals, they threaten the necessary conditions $^{3}$ for life and wellbeing. Determining whether and when non-human animals have rights

\footnotetext{
${ }^{1}$ This claim has been extensively debated elsewhere and I shall not defend it here. For some defences of animal rights see: Tom Regan, Defending Animal Rights (Champaign, IL: University of Illinois Press, 2001); Tom Regan and Carl Cohen, eds., The Animal Rights Debate (Lanham: Rowman and Littlefield, 2001); David DeGrazia, Animal Rights: A Very Short Introduction (Oxford: Oxford University Press, 2002); Gary L. Francione and Robert Garner, The Animal Rights Debate: Abolition or Regulation? (New York: Columbia University Press, 2010); Robert Garner, A Theory of Justice for Animals: Animal Rights in a Nonideal World (OUP USA, 2013); Alasdair Cochrane, An Introduction to Animals and Political Theory (Hampshire: Palgrave Macmillan, 2010); Christine Korsgaard, 'Fellow Creatures: Kantian Ethics and Our Duties to Animals.', Tanner Lectures on Human Values, no. 24 (2004): 77-110.

${ }^{2}$ Cf. John Rawls, A Theory of Justice: Revised Edition (Cambridge, Massachusetts: Belknap Press of Harvard University Press, 1999), 3-4.

${ }^{3}$ A habitat is a geographically defined area which provides the natural conditions for an organism to live and grow.
} 
to their habitats, and how those habitat rights are configured, are therefore important questions to consider.

If some non-human animals have habitat rights then we will need to know when the right applies, how it is configured, and what duties are associated with it. In the first section of the paper I argue that habitat rights are generated where habitats are a necessary condition of an animal's survival or wellbeing. Although, in traditional environmental conservationist paradigms, some consideration has been given to the interests of wild animals in their habitats, animals have not been conceived as rights-bearers. As a result, protecting habitats has been contingent upon their instrumental or aesthetic value to humans not being outweighed by any other factors. Consequently, habitats continue to be destroyed at an alarming rate, with resultant threats to the animals within them. In order to address this problem, I follow on from the foundation of habitat rights with ways in which they can be instantiated. First, I argue that limited usufructuary property can succeed in protecting the habitats of wild animals, but that a fuller configuration of property rights, including the power to transfer and waive those rights, does not meet animal needs. Furthermore, I claim that where habitat rights are systematically and seriously violated, non-human animals can, in some circumstances, gain remedial rights of secession and a form of partial sovereignty over their territory. Although others have also argued that wild animals have sovereignty rights, ${ }^{4}$ their claims have been based upon a stronger conception of animal sovereignty than I advance, and are based upon a primary right to secession. I reject these claims on the grounds that they rely upon overly attenuated conceptions of sovereignty, which strip sovereignty of much of its meaning and normative force, and because the primary right to secession is justified on a level of autonomy that non-human animals simply do not possess. The remedial right to secession and models of partial sovereignty I

\footnotetext{
${ }^{4}$ Donaldson and Kymlicka, Zoopolis: A Political Theory of Animal Rights, chap. 6; Goodin, Pateman, and Pateman, 'Simian Sovereignty'.
} 
advance are not grounded in the value of autonomy and so do not suffer from the same problems.

Each of the rights I describe relies upon third parties, in the form of advocates, trustees,

organisations, or citizens, to press claims on behalf of the right-holder; a topic I expand upon in

discussion models of partial sovereignty based upon protectorate and trusteeship territories.

\section{Grounding habitat rights}

An animal's right to its habitat arises out of the strong interests it has in living within that habitat.

At least some animals depend upon their habitat for their survival; they have adapted to features of their habitat such that were it to disappear, then their existence would also be threatened. The Leadbeater's possum, for example, requires quite specific forest conditions to meet its food and nesting needs. Without trees in the correct combination of young-, mid-, and old-growth, the possums cannot survive. As a result, logging and bushfires in the possums' habitat have caused their numbers to fall to an estimated $1500 . .^{5}$ If an animal's interest in continued existence is strong enough to generate duties in others ${ }^{6}$ not to kill it, then it will also generate a right not to be deprived of the conditions necessary for living. One way in which death harms non-human animals is in the loss of opportunities for pleasurable experiences. It is generally in an animal's interests to experience pleasure; death sets back that interest; therefore death is harmful. For animals with a persistent psychological identity ${ }^{7}$ - ones with memories and future directed desires - the interest in living is stronger because they may look forward to the enjoyment of goods and recall past pleasant experiences. The lives of these animals matter to them, and thus they have an interest in continuing

\footnotetext{
${ }^{5}$ Oliver Milman, 'Government-Backed Logging "Pushing Rare Possum towards Extinction"', The Guardian, 26 May 2013, sec. Environment, http://www.theguardian.com/environment/2013/may/26/logging-pushing-possum-towardsextinction.

${ }^{6}$ Under the interest theory of rights, rights arise out of sufficiently strong interests. Where interests are strong enough to impose duties, then they justify rights. See, Joel Feinberg, 'The Rights of Animals and Unborn Generations', in Ethical Theory: An Anthology, ed. Russ Shafer-Landau, 2 edition (Chichester, West Sussex ; Malden, MA: Wiley-Blackwell, 2012); Joseph Raz, The Morality of Freedom (Oxford: Oxford University Press, 1988), 166.

${ }^{7}$ Tom Regan refers to these animals as being 'subjects-of-a-life'. See, Tom Regan, The Case for Animal Rights, 2nd ed. (Berkeley and Los Angeles: University of California Press, 2004), 243.
} 
to exist. ${ }^{8}$ Some animals, such as dolphins and great apes, are probably also cognitively developed enough to make plans and pursue more sophisticated goals with at least some degree of autonomy. For those animals, death will constitute an even greater setting-back of interests. Thus, where the right generated by an interest in continued existence is tied-up in the preservation of a habitat, the right to that habitat becomes a basic right. ${ }^{9}$

For some animals, although access to habitat is not needed for survival it is a necessary condition of their wellbeing. ${ }^{10}$ Take orangutans: orangutans live most of their lives in trees, feeding off fruits, bark, leaves, honey, and insects. They create nests from leaves to sleep in, make umbrellas from them to shelter from the rain under, and use the plant-life in their habitats to make medicinal treatments. ${ }^{11}$ Their habitat provides orangutans with both sustenance and shelter. Most of an orangutan's day is spent travelling within its habitat, resting, and foraging. Over time, wild orangutans have developed cultures of their own, with socially based learning transmitting cultural elements in the form of labels, signals, and skills. ${ }^{12}$ These orangutan cultures differentiate orangutan populations by geographical location. In captivity the wellbeing of primates has been shown to suffer the less the conditions in which they are held resemble their natural habitat. ${ }^{13}$ Together, these facts about orangutan existence suggest that they have a sufficiently strong interest in their habitat to generate a prima facie right to it. Their happiness and vital components of their wellbeing depend

\footnotetext{
${ }^{8}$ See Tom Regan, The Case for Animal Rights, 2nd ed. (Berkeley and Los Angeles: University of California Press, 2004), 99-103; Alasdair Cochrane, Animal Rights without Liberation: Applied Ethics and Human Obligations (New York: Columbia University Press, 2012), 65-71.

${ }^{9}$ See Henry Shue, Basic Rights, 2nd ed. (Princeton University Press, 1996).

${ }^{10}$ Of course, whilst it is true for many individual animals that access to their habitat is not a necessary condition of their survival, it is also true that the possibility of living in captivity is not open for most - there simply isn't capacity. Thus, habitat destruction will mean loss of life for at least some, if not many, non-human animals for whom their habitat is not necessary to their survival at the individual level.

${ }^{11}$ Helen Celia Morrogh-Bernard, 'Fur-Rubbing as a Form of Self-Medication in Pongo Pygmaeus', International Journal of Primatology 29, no. 4 (18 June 2008): 1059-64.

${ }^{12}$ Cf. Carel P. van Schaik et al., 'Orangutan Cultures and the Evolution of Material Culture', Science 299, no. 5603 (3 January 2003): 104-105; Robert W. Shumaker, Orangutans (MBI Publishing Company, 2007), 56; Felipe FernándezArmesto, So You Think You're Human?: A Brief History of Humankind, 2005, 56-57.

${ }^{13}$ Lucy Birkett and William McGrew, “Unnatural Behavior” Obstacle or Insight at the Species Interface?', in The Politics of Species: Reshaping Our Relationships with Other Animals, ed. Raymond Corbey and Annette Lanjouw (Cambridge University Press, 2013).
} 
upon living within their habitat. Many other communities of wild non-human animals can have similar arguments made for them.

\section{The dominant paradigm of habitat conservation}

To an extent, the interest non-human animals have in their habitats is recognised in traditional models of conservation management, which can be characterised in terms of stewardship. Under stewardship approaches, ${ }^{14}$ habitats are protected because it is recognised that they contribute to the survival of species of plants and animals within them, and in order to provide aesthetic enjoyment for humans. Habitats are thus preserved not for the sake of individual non-human animals, but because value is placed upon species and ecosystems in order to benefit humans. Stewardship, in the form of legal protections for habitats such as national parks and wilderness areas, can provide a way to protect habitat rights since not all moral rights need to be protected through the creation of a corresponding legal right. ${ }^{15}$ However, stewardship has consistently proven insufficient for the protection of habitats, and they continue to be destroyed. As Robert Goodin, Carole Pateman, and Roy Pateman point out, stewardship means that the land animals depend upon remains ours rather than theirs, ${ }^{16}$ leaving the protection of animal interests dependent upon human goodwill. Because non-human animals do not have their rights recognised, their habitat interests are often overridden in the name of promoting social goods (logging, draining, dredging, road-building etc.), or are trumped by the interests of those whose rights are recognised (humans). Acknowledging that nonhuman animals have rights to their habitats means that they have claims that cannot simply be trumped by social goods and the interests of humans. Because of this, approaches to habitat protection should proceed from the basis that individual non-human animals are worthy of moral

\footnotetext{
${ }^{14}$ Cf. John Passmore, 'Attitudes to Nature', Royal Institute of Philosophy Supplements 8 (March 1974): 251-64.

${ }^{15}$ Jeremy Waldron, 'A Right-Based Critique of Constitutional Rights', Oxford Journal of Legal Studies 13, no. 1 (1 April 1993): 23-25.

${ }^{16}$ Goodin, Pateman, and Pateman, 'Simian Sovereignty', 835.
} 
concern for their own sakes and that they can have rights to their habitats as a result. ${ }^{17}$ This conclusion requires us to consider how we should characterise habitat rights and what they demand of us.

\section{Habitat rights as property rights}

Initially, the rights of non-human animals to their habitats could be instantiated as property rights.

For example, Nussbaum argues that non-human animals have something analogous to property rights over their habitats. ${ }^{18}$ She derives these from a right to the capabilities necessary for a being to flourish, which includes the capability to exercise "control over one's environment." 19 Similarly, Hadley argues that the interests non-human animals have in their habitats are sufficiently strong as to generate property rights, rights which include the power to transfer land ownership, the right to use land, and the power to exclude others from it. ${ }^{20}$ Property rights are a promising means of ensuring habitat rights are respected because they offer a stronger method of dealing with noncompliance than stewardship approaches. If animals are owners of their habitats then they can claim, through their trustees, compensation for wrongs done and move for the enforcement of their rights through legal means. Animals might come to own property by being gifted it, perhaps

\footnotetext{
${ }^{17}$ The animal rights approach to habitat preservation also differs substantially in its foundation from ecological approaches. Where the animal rights approach sees the value of habitat in its contribution to the wellbeing of individual sentient life, the ecological approach is grounded in a claim that habitats, ecosystems, parts of the landscape, and species have intrinsic value separate from (and above) the value of the organisms that comprise them. The starting point of an ecocentric approach is to preserve the integrity of an ecological system for its own sake rather than for the animals that depend upon it. Ecocentrism provides a justification for protecting habitats but does not grant non-human animals any right to those habitats. A defence of sentience-based rights over ecocentric approaches is beyond the scope of this paper, however, there are reasons to think that ecocentric and rights-based approaches to habitat protection and preservation can align at the level of outcomes. In practice, a principle aimed at preserving ecosystems for their own sakes is likely to result in the interests of non-human animals have in their habitats being met. Different reasons may be offered for habitat preservation, but the end result remains habitat preservation - much in the same way that state sovereignty can be justified on both communitarian and individualist grounds (cf. Bryan G. Norton, Toward Unity among Environmentalists (New York: Oxford University Press, 1994).

${ }^{18}$ Nussbaum, Frontiers of Justice, 400.

${ }^{19}$ Ibid.

${ }^{20}$ John Hadley, 'Nonhuman Animal Property: Reconciling Environmentalism and Animal Rights', Journal of Social Philosophy 36, no. 3 (2005): 305-15.
} 
through debt-for-nature swaps $;{ }^{21}$ as compensation for injustice; or as rectification for the violation of a pressing historical claim. ${ }^{22}$

However, there are problems with granting full property rights over their habitats to non-human animals. One such problem is that it is difficult to see how being able to alienate their habitat rights would contribute to wellbeing or interest satisfaction when those things depend upon the habitat in the first place. The interests non-human animals have in their habitats can be met by ensuring they have use of the habitat rather than having powers to sell their property. This means that full property rights are not necessary to protect habitats, and that mere usufructuary rights paradoxically represent a stronger rights configuration for animals. Furthermore, provided they are unharmed by it, these usufructuary rights can be shared with others, allowing humans and non-humans to live together in mutually beneficial ways and potentially generating revenue streams for animal trustees to manage habitats with. One benefit of this approach is that, whilst non-human animals would gain stronger protection, little would need to change on the surface in terms of management, usage, and territorial control of land. It is clearly possible for non-human animals to enjoy their habitats without having full property right to those habitats, provided that their rights are respected by moral agents. Full ownership is not a necessary condition for the satisfaction of animal interests in their habitat. A further factor to take into consideration is that unless the animal is solitary, then it does not make sense to assign property rights at the individual level. Whilst their dependency upon their habitat makes it unlikely that non-human animals will leave their habitats, the fact that they are not rational moral agents means that they are unable to respect one another's property rights within that habitat, and they cannot be held accountable for rights violations. Nor would an individual nonhuman animal be able to sell his own property and then exclude himself from the property of other

\footnotetext{
${ }^{21}$ As mooted by Goodin, Pateman, and Pateman, ‘Simian Sovereignty', 837.

22 If non-human animals can be property owners, then it may also be that they have valid historical claims to initial acquisition of land, which has since been unjustly acquired from them by human communities.
} 
members of his species. For these sorts of reasons, animal property rights need to be vested in collectives, consisting of all of those animals with sufficiently strong interests in a habitat, rather than individual animals.

\section{From property rights to territorial and secession rights}

Ownership of their habitat enables the rights of non-human animals to be better protected than stewardship approaches to habitat protection, but they will not always be sufficient. A brief return to the situation orangutans find themselves in helps illustrate why not. Loss of orangutan habitat has resulted in drastic reductions in orangutan numbers and put them at risk of species extinction. In just 100 years their numbers have fallen from 315,000 to 6,600 in Sumatra and less than 54,000 in Borneo. ${ }^{23}$ In Sumatra, there are now only three remaining populations of greater than 500 , the minimum number considered genetically viable for long term survival. ${ }^{24}$ Although they have been protected from being owned, killed, or captured under Indonesian law since 1931, they are frequently hunted for pets, ${ }^{25}$ killed as agricultural pests, and occasionally killed for food. ${ }^{26}$ However, the greatest threat they face is from the destruction of their habitat through both legal and illegal logging and its replacement with oil palm plantations and other agricultural land. ${ }^{27}$ Their numbers have declined by $80 \%$ in the last 75 years and continue to do so ${ }^{28}$ despite the supposed protections of domestic Indonesian law, the efforts of conservationists, and despite international law prohibiting their trade and setting them a protected status. ${ }^{29}$ Loss of orangutan habitat results from the deliberate actions of the state, and because the state lacks the capacity or the will enforce the

\footnotetext{
23 'Orangutan Facts - Sumatran Orangutan Society':, accessed 4 January 2012, http://www.orangutanssos.org/kids/orangutan_facts.

24 'Orangutan Crisis - Sumatran Orangutan Society', accessed 4 January 2012, http://www.orangutanssos.org/orangutans/crisis.

25 'Pongo Abelii (Sumatran Orangutan)', The IUCN Red List of Threatened Species, accessed 4 January 2012, http://www.iucnredlist.org/apps/redlist/details/39780/0.

26 'Orangutan Crisis - Sumatran Orangutan Society'.

27 'Pongo Abelii (Sumatran Orangutan)'.

${ }^{28}$ Ibid.

${ }^{29}$ Convention on International Trade in Endangered Species of Wild Fauna and Flora (CITES). Washington, March 3 , 1973, 993 U.N.T.S. 243, Appendix 1.
} 
law. Domestic and international legal protections have each failed the orangutans. It may be that if orangutans could have legal claims made on their behalf, then there would be fewer violations of their rights, but if states lack enforcement capacity or are complicit in rights violations then a problem remains. $^{30}$

Additionally, because their habitats fall within the territory of a nation-state, any potential ownership rights orangutans might be granted can be changed or removed at the whim of the state. The danger exists both because orangutans have no meaningful voice in the political processes within their parent nation, and because of the nature of the state's territorial rights. The most convincing and commonly adopted theory of territorial rights sees them as a bundle of state jurisdictional and meta-jurisdictional powers, distinct and non-derivative of property rights. A state's jurisdictional rights constitute Hohfeldian ${ }^{31}$ powers to regulate and enforce property rights over land. Its meta-jurisdictional power is that of determining who holds jurisdictional power over pieces of territory. ${ }^{32}$ Because states have jurisdictional power to alter property rights within their territory, they are able strip animals of any property rights they have gained. Animals are uniquely vulnerable to injustice because they have no political voice of their own (nor the possibility of one). Non-human animals rely upon humans to speak up for them, and it is thus easier to ignore or overlook their claims. In human cases, individuals or groups can challenge the decisions of states and seek compensation for property that is compulsorily purchased or taken from them. However, the interest non-human animals have in their habitats cannot be compensated for in the same way since they depend upon it for survival or wellbeing. Unless non-human animals can be transplanted into a similar habitat with little or no loss to their wellbeing, the idea of restitution or compensation

\footnotetext{
${ }^{30}$ Cf. Donaldson and Kymlicka, Zoopolis: A Political Theory of Animal Rights, 178.

${ }^{31}$ See Wesley Newcomb Hohfeld, 'Fundamental Legal Conceptions as Applied in Judicial Reasoning', The Yale Law Journal 26, no. 8 (June 1917): 710-70.

${ }^{32}$ Cf. Cara Nine, 'Territory Is Not Derived from Property: A Response to Steiner', Political Studies 56, no. 4 (2008): 958; Anna Stilz, 'Why Do States Have Territorial Rights?', International Theory 1, no. 02 (2009): 196.
} 
is meaningless. Non-human animals are therefore at greater risk of rights violations in respect of their property than human owners.

In cases where vital habitats are threatened and animal rights violated in spite of legal protections, the situation non-human animals find themselves in is akin to that of regional human communities whose rights are seriously and systematically threatened by their parent political community. For humans, serious rights violations can generate a remedial right to secession. The remedial right to secession is a right of last resort to escape serious and systematic violations of basic rights - it is a means of escape in the face of serious injustice. ${ }^{33}$ If non-human animals have habitat rights, then in certain circumstances they, like human communities, may also gain a remedial right to secession.

Where human communities gain a right to secession, the right is anchored to a particular place and a group identity. Although habitats are geographically defined, few, if any, non-human animals have attachments to a place in a way that is tied to their conception of the good. In other words, if the physical attributes of a habitat could be replicated in a different location, then non-human animals would be equally happy with either place. Unlike persons, most non-human animals likely do not base attachments upon historical contingencies. For human communities, a facsimile of a place that is constitutive of identity is no substitute for the real place. This means that whilst it can be argued that non-human animals have rights to territory, it is difficult to connect that right to any geographical location. Two responses to this problem present themselves. First, one might think that the animals' occupancy of a place creates a claim-right to that place, particularly if populations of wild animals have existed there for some time. We might go so far as to claim that human ownership is presaged on unjust acquisition from the original owners of a place (the animals). Second, as with the Leadbeater's possum, it is sometimes the case that key features of a habitat are

\footnotetext{
${ }^{33}$ Allen Buchanan, 'The Making and Unmaking of Boundaries: What Liberalism Has to Say', in States Nations and Borders, ed. Allen Buchanan and Margaret Moore (Cambridge University Press, 2003), 247.
} 
not replicable elsewhere; soil conditions, climate; altitude etc., make it impossible to successfully transplant an animal ecosystem to another place. If the non-contingent goods of non-human animals depend upon such non-replicable and non-transferable features of their habitat then their claim to it could be stronger even than that of human communities with an identity-based connection.

\section{Animal sovereignty}

The idea that non-human animals have territorial rights over their habitats is not a new one. In 'Simian Sovereignty' Goodin et al argue that the Great Apes hold de facto control over their habitats, the capability to live autonomously, and a sufficiently social existence to generate a claim to sovereignty. ${ }^{34}$ Donaldson and Kymlicka build upon this argument and extend the claim to all wild animals. They argue that wild animals have an interest in self-determination, are competent to face their own challenges and pursue their own goods, are organised into communities, and desire to be left alone. ${ }^{35}$ As a result, our interactions with wild animals should be governed by the requirements of respect for sovereignty. ${ }^{36}$ In this way wild animals can be granted a protected sphere in which to live independently and be shielded from threats to their habitats or territories. Donaldson and Kymlicka see parallels between the injustices suffered by human communities 'whose self-government and sovereign control of their territory have historically been denied' and the destruction of habitats. ${ }^{37}$ Just as in the case of human communities, acts of aggression, colonisation, and displacement can all be prohibited by adopting norms of sovereignty. The ability of wild animals to live self-directed lives and to take care of and manage their communities and territories without human intervention is seen by Donaldson and Kymlicka as analogous to selfdetermination in human communities. ${ }^{38}$ What matters, they claim, is that non-human animals are

\footnotetext{
${ }^{34}$ Goodin, Pateman, and Pateman, 'Simian Sovereignty'.

${ }^{35}$ Donaldson and Kymlicka, Zoopolis: A Political Theory of Animal Rights, 174-179.

${ }^{36}$ Ibid., 178.

${ }^{37}$ Ibid., 168

${ }^{38}$ Ibid., 174-179.
} 
able to respond to community challenges and 'provide a social context in which [a community's] individual members can grow and flourish. ${ }^{39}$

Donaldson and Kymlicka's conception of sovereignty is derived from autonomy-based individual rights to self-determination. Their claim is that the normative case for the sovereignty of wild animals is the same as it is for human political communities: just as humans need sovereignty in order to live self-directed, autonomous lives, so too do wild animals. In the course of their argument, Donaldson and Kymlicka draw attention to the injustices and harmful effects caused by human encroachment on or destruction of habitat through development, pollution, climate change, or accident. Making non-human animals sovereign over their habitats is one way of protecting and preserving them against these harms. Because the concept of sovereignty carries considerable normative force, and because there are long-standing international norms and institutions in place around it, wild animal sovereignty potentially constitutes a powerful protective arrangement for animal rights.

The right to sovereignty over their habitat developed in Donaldson and Kymlicka Zoopolis differs from the remedial right that I describe. Although they raise sovereignty as a means of addressing injustice, Donaldson and Kymlicka seem to be making the claim that wild animals have what Buchanan describes as 'primary rights' of secession. These primary rights of secession exist in cases where the majority of a region's residents choose to secede from their parent community or in cases where a group shares a common characteristic, such as a common culture or particular attachment to an area. ${ }^{40}$ In neither case are serious injustices a necessary condition for the possession of a right of secession, they are derived merely from the basic right of self-determination. ${ }^{41}$ The purpose of this right in Zoopolis is to allow wild animals to enjoy fair terms of cooperation with human

\footnotetext{
${ }^{39}$ Ibid., 176.

${ }^{40}$ Ibid., 248.

${ }^{41}$ Ibid., 249.
} 
political communities; to prevent encroachment and destruction rather than to respond to it. Donaldson and Kymlicka's argument is forward-looking; it presents claims about ideal political arrangements necessary to satisfy the demands of justice. In contrast, the remedial right to secession arises in response to injustice and does not depend upon the overly attenuated notion of selfdetermination built into Donaldson and Kymlicka's conception of sovereignty. Remedial rights escape this problem because they are justified as a response to violations of basic rights rather than in terms of the exercise of autonomy.

Donaldson and Kymlicka's argument is that the ability of wild-animals to live self-directed lives, and flourish free from human interference generates the same right to self-determination that the capacity for autonomy does in human persons. The upshot of this right to self-determination is sovereignty rights over territorial space. Traditionally, the right to self-determination is justified as a foundation for the realisation of other fundamental rights by reference to the autonomy, inherent dignity, and moral equality of the human person; it affirms the rights of peoples to control and freely dispose of the resources within their territories. The goal of self-determination is considered to be sovereignty, which provides the circumstance within which political, civil, and economic rights can best be realised.

Unfortunately, the case made by Donaldson and Kymlicka for animal sovereignty rests upon dubious claims about the interest animals have in self-determination. In order to argue that animals should be sovereign Donaldson and Kymlicka are forced to redefine autonomy and sovereignty to such a degree that the concepts lose both normative power and conceptual usefulness. Simply put, to claim that the general self-reliance of non-human animals is analogous to political selfdetermination goes too far. Territorial sovereignty is individual autonomy - authorship over one's life - writ large. Non-human animals lack the capacity for the kind of autonomy necessarily at the heart of human rights regimes, and their interest in liberty is qualitatively different from that of 
humans. ${ }^{42}$ The concept of autonomy at work in the justification of sovereignty is that of being able to live a self-directed life in the context of a conception of the good, and to be responsible for one's actions. This concept of autonomy depends upon self-consciousness and the ability to have and act upon second-order desires. It is primarily because autonomous agents choose and are invested in their plans, and because the act of choosing is constitutive of both the good life and what it means to be a moral agent, that it is wrong to constrain them. For these reasons animals cannot be said to aspire to, or to realise, self-determination and therefore sovereignty. The very rights that the modern conception of sovereignty is both a part of and a protection of are presaged on the idea of the human as an autonomous chooser of his or her own rational and revisable life plans. Sovereignty through self-determination is an expression of the choices of the citizen. Non-human animals on the other hand do not need their autonomy protected because they are not autonomous in the same way that rational beings can be. ${ }^{43}$ To claim sovereignty for non-human animals runs the risk of devaluing the human rights that sovereignty is ideally supposed to embody and protect. The human rights that the move from self-determination to sovereignty are supposed to foster and realise simply do not directly map on to the kind of rights envisioned by most animal rights theorists.

One reply to this might be to say that although wild animals do not live in political communities, or exercise autonomy like humans do, there are some that come close enough for the idea of sovereignty based upon the authority of a self-directed community over a territory to be applicable. In their paper, Goodin et al assert that many of the great apes, with their structured, hierarchical communities and ability to communicate in complex ways, do exercise authority over a territory and can therefore be said to have met the conditions of a classical Westphalian conception of

\footnotetext{
${ }^{42}$ Cf. Alasdair Cochrane, 'Do Animals Have an Interest in Liberty?', Political Studies 57, no. 3 (2009): 660-79; James Rachels, 'Do Animals Have a Right to Liberty?', in Animal Rights and Human Obligations, ed. Tom Regan and Peter Singer (London: Prentice-Hall, 1976).

${ }^{43}$ None of this should be taken as a claim that animals do not have an interest in liberty and that it is therefore never wrong to constrain them. Rather, non-human animals may have an interest in liberty which, whilst it is qualitatively different from that of autonomous agents, nevertheless makes it wrong to constrain them without good reason.
} 
Forthcoming in Environmental Values @ The White Horse Press http://www.whpress.co.uk

sovereignty. ${ }^{44}$ Thus the principle of 'mutual non-interference' central to that conception can be applied to non-human species of great apes reasonably straightforwardly (providing that the apes are non-migratory). Other species could also be said to be dominant over an area, such as wolves, bears, large deer etc.

However, even conceding that a more classical conception of sovereignty than contemporary international norms lean towards can be maintained, dominance as an aggressive or predatory species is not the same as authority, nor does it constitute normative grounds for privileging one species over another. Authority is not simply the ability to coerce others to enact the will of the powerful, rather, it is the right to be obeyed, and a right that carries moral force and that is considered to be legitimated though consent. Complex creatures like great apes might possibly be sophisticated enough to constitute a special case for animal sovereignty, as would seem to be the inference in Goodin et al, but Kymlicka and Donaldson want to apply arguments for animal sovereignty to the more problematic case of all sentient animals in a territory, and to the menagerie of different species in corporate form rather than to a single species in a given habitat. Notions of community, autonomy, and legitimacy simply cannot, by definition, apply to the lives of different wild animals living and competing in a given geographical area. When Donaldson and Kymlicka describe wild animals as autonomous and as existing in organised communities with rights to authority over a given territory they stretch too many concepts too far.

A remedial right to secession, in response to sustained and serious animal rights violations, does not require an autonomy based justification. Indeed, in the case of humans the right is justified on grounds of systematic and serious injustice or rights violations - it is not necessarily connected with autonomy. However, although the normative justification for primary rights to secession can be different from that for remedial rights to secession, the end result appears to be territorial

\footnotetext{
${ }^{44}$ Goodin, Pateman, and Pateman, 'Simian Sovereignty', 833-834.
} 
sovereignty in each case. If this is so, then the same problems that afflict Donaldson and Kymlicka's argument will be present in mine: animals simply cannot be sovereigns. Fortunately there are ways to instantiate territorial rights that stop short of autonomy-based sovereignty as self-determination, and these models have already been applied in the non-ideal. Goodin et al suggest an international trusteeship system modelled on the established legal norms associated with Protectorates and United Nations Trusts. ${ }^{45}$ Each of these two systems of governance is a suitable candidate for regulating the interactions of political communities with the habitats of wild animals and neither is subject to the conceptual problems associated with the idea of full sovereignty. Protectorates and trusteeships allow for proxy representation by humans as a means for animal territories to interact with international legal institutions. Proxy representation and the establishment of territorial rights through protectorates and trusts are a long way from the norms and values of full sovereignty. Nevertheless, these two models can provide for the flourishing of wild animals and protect them against the kind of historic injustices of suffered by colonised and oppressed human peoples.

Protectorates are territories with distinct borders that are protected by a patron state, and whose existence is proclaimed by that state. Protectorates have their own internal governments; either determined internally or imposed by the patron state, whilst their foreign and defence matters are governed by their patron. In 1945 the UN formed a Trusteeship Council of UN membership states to oversee the decolonisation of dependent territories. Eleven territories were placed under trusteeship of the council. The last trust territory, Palau, became a full member state of the UN on October $1^{\text {st }} 1994$. Despite this, the council still exists, although it no longer meets and its operations are suspended. Articles 75-91 of the Charter of the United Nations established an international trusteeship system of United Nations administered and supervised territories and contains provisions for designating governing authorities. Interestingly, the UN's Commission on Global

\footnotetext{
${ }^{45}$ Goodin, Pateman, and Pateman, 'Simian Sovereignty’, 834-836.
} 
Governance issued a report in 1994, 'Our Global Neighbourhood', which included a recommendation that 'The Trusteeship Council should be given a new mandate over the global commons in the context of concern for the security of the planet'. ${ }^{46}$ They even went as far as recommending including members of civil society in the council. ${ }^{47}$ These trusteeships were set up to protect the human rights of inhabitants of trustee territories under a mandated set of rules of governance. In stating that the 'trusteeship system shall not apply to territories which have become Members of the United Nations' because their relationships are 'based on respect for the principle of sovereign equality' Article 78 sets trustee territories at a lower status to sovereign states. This different legal status is unavoidable given that the theoretical equality of sovereign states is based upon mutual respect and reciprocity: with their foreign and defence matters controlled by a patron state trusteeships and protectorates cannot act reciprocally. Given the status of non-human animals as non-moral beings with limited capacities for mutual arrangements, this different status, presaged on a lack of capacity for reciprocity, fits animal territories well. The use of trusteeships and protectorates in place of territorial sovereignty thus better explains how human political communities might interact with non-human animals in the wilderness than full sovereignty. And it does so without needing to stretch, attenuate, or redefine key normative and political concepts. As far as wild animals are concerned, it does not matter to them whether their territory is considered sovereign or semi-sovereign; what matters is that the implications for them in living within a protectorate, trust or fully sovereign territory are practically the same. The interests of the animals themselves determine how external political communities relate to them.

A further reason to reject primary secession rights is that they require far more complex moral and legal arguments to resolve than remedial rights. So long as non-human animals have their habitat-

\footnotetext{
${ }^{46}$ Commission on Global Governance, Our Global Neighbourhood: The Report of the Commission on Global Governance (Oxford Paperbacks, 1995), 345.

${ }^{47}$ Ibid., 251-263.
} 
based interests met, there is no need to attempt to resolve disputed territorial claims, determine who has prior claims, or place vast swathes of wilderness in international control. The existence of a primary right to secede would require complex decision-making and arbitration processes tracing historic claims and establishing trustee systems for an amount of land limited only by the boundaries of the planet itself. Responding solely to serious rights violations makes managing animal territorial claims far less burdensome and is much more achievable.

In practice the two models of partial sovereignty described above can be applied to the different territorial status of various habitats: protectorates could be established over habitats within the borders of sovereign states, whilst trusteeships could govern territories in unclaimed or contested spaces: such as conflict zones, the oceans, parts of the Polar Regions etc. In the domestic sphere national governments could appoint a governing body to look after the internal matters of the protectorates, acting in the interests of the animals within the habitat. Where animal territories overlap multi-state joint governing bodies could be appointed. As an example: an animal trusteeship could involve an international body, such as the United Nations Trusteeship Council, charging some political or administrative body or bodies (perhaps including national and NGO representatives) with governing and representing a particular habitat or animal community. The UN might take a lead implementation role and act as a supervisory body over the mandated governance structures. The terms by which the trusteeship should operate, and the duties of the governing body toward the habitat or animal community would be established by the UN - together with the rights of governance.

These two forms of partial sovereignty ensure that decisions taken about the animals and their territory are taken in the interests of the animals themselves, without the need to re-define existing concepts like sovereignty and autonomy, or apply ill-fitting concepts such as authority, selfdetermination, or community to the non-human inhabitants of wilderness areas. Animals are 
explicitly not self-determining in the sense that we use when we talk about human political communities; but they can benefit from being left alone, and by being considered the rightful owners, protected by international law, of the land they occupy. With animals within a territory left largely to their own devices, and their external borders protected from encroachment, a reduced kind of sovereignty would exist. And it is possible to imagine human beings living within these animal protectorates provided their development of the territory was kept within agreed limits, and perhaps even paying rent or leasing the land from the animals.

\section{Conflicts of rights}

One question the interest-based approach to habitats rights raises is how to deal with conflicts of interests, particularly between humans and non-human animals. Many political theorists have argued that the protection of the environment is necessary to the realisation of other rights and interests and so human beings have strong environmental rights. ${ }^{48}$ If both humans and animals have rights to a particular habitat, then how should the conflict be settled? The first thing to be said is that not all conflicts of interests are conflicts of rights; simply having an interest in the environment isn't sufficient to generate a right to it. To generate rights, interests must be sufficiently strong as to place another under an enforceable duty. ${ }^{49}$ Thus, and since these rights exist to protect interests rather than maximise them, ${ }^{50}$ a human interest in improving wellbeing will not be sufficient to overcome an animal right to continued existence or against being made to suffer. This means that a human interest in improving transport links would not be sufficient to generate a right to build a motorway

\footnotetext{
${ }^{48}$ Brian Barry, 'Sustainability and Intergenerational Justice', Theoria: A Journal of Social and Political Theory, no. 89 (1 June 1997): 43-64; Tim Hayward, Constitutional Environmental Rights, vol. 14, 4 (Oxford: Oxford University Press, 2004); David Miller, 'Social Justice and Environmental Goods', in Fairness and Futurity, ed. Andrew Dobson (Oxford: Oxford University Press, 1999); Dinah Shelton, 'Human Rights, Environmental Rights, and the Right to Environment', Stanford Journal of International Law 28 (1992 1991): 103.

49 Joseph Raz, The Morality of Freedom (Oxford: Oxford University Press, 1988), 166.

${ }^{50}$ It is worth pointing out that in any case, human rights to a decent environment, sustained into the future, may be well served by the preservation of animal habitats.
} 
through the vital habitat of a non-human animal: ${ }^{51}$ rights trump utility. But what if human interests in an animal's habitat are sufficiently strong as to generate rights to that habitat? Perhaps some particular humans are in dire need and must make use of an animal's habitat in order to survive. In these cases we ought to think of the habitat rights of non-human animals as pro tanto rights. The reason for this is that in most cases the human interest in survival will carry more moral weight, by dint of their richer set of preferences, projects, and future-directed goals, than that of non-human animals. Thus, the right of a rational agent to survive overcomes the survival right of a merely sentient being. But, if the survival need of the rational agent can be met without violating the habitat right of the merely sentient being, then violating that right is not justified. The fact that death counts as a bigger harm for rational agents than merely sentient beings does not support a claim that therefore rational agents may do as they will with non-rational beings. In all cases where the basic rights of a rational agent conflict with that of a merely sentient being, a traditional interest theory of rights will be forced to place the rights of the rational agent above those of the merely sentient being. For many animals, their habitat (as I have argued) should be considered a basic right, upon which other rights depend. This means that the preservation of habitat rights will be lexically prior to the protection of other sorts of rights. Thus, an animal's basic habitat right will trump a non-basic human right. In other cases, where non-human habitat rights conflict with human rights such that they can be considered like cases, some form of balancing procedure or other system of rights mediation will need to be employed, but there is no reason to think that this needs to be any different than those currently used in clashes of human rights. Breaches of pro tanto habitat rights following these procedures are likely to result in requirements to compensate (such as by providing a suitable replacement habitat elsewhere or improving some other aspect of the animal's wellbeing).

\footnotetext{
${ }^{51}$ Although it would not preclude ensuring an animal's habitat rights are met by moving it to another suitable habitat in many cases the animal's right will be to a habitat rather than to a specifically sited habitat.
} 
Crucially however, a human right will not trump an animal's habitat right simply because it is a human right.

\section{Governing animal territories}

Acting in the interests of animals within a territory is still subject to any number of practical issues, not least the epistemic problem of being able to know what is in an animal's interests and how those interests relate to the interests of other animals in the territory. I assume that whilst this problem might be difficult to solve, it seems, at any rate in principle, possible to achieve. Additionally, there is the issue of whether the governance structure should be resourced using the natural resources of the territory being governed (leading to the potential for very rich and very poor habitats). However, short of dealing with large scale threats to habitats and populations within the protectorates it seems, superficially at least, that any governing body in control of the domestic affairs of an animal protectorate would have relatively little to do (compared with a state or provincial government) beyond representing that protectorate's interests to its patron state, or to make representations to other sovereign bodies in the event of failings of the patron. The reason for this is that animal territories are likely to be smaller than most nation states and less complex. They will be less complex because they will not require the range of social, political, and economic institutions required to regulate the social interactions of autonomous agents, and because non-human animals require less support to live independent lives than humans.

\section{The problem of paternalism?}

The provisions of the United Nations on trusteeships envision their existence as a stepping stone towards eventual self-determination and full sovereignty. However, it is impossible to see how wild animals might ever reach this stage, and so animal trusteeships would necessarily have to be permanent affairs. It might be suggested at this point that this therefore makes the trusteeship and protectorate models forced in the same way that I have argued Donaldson and Kymlicka's 
sovereignty model is. To some extent this is true, but, given that international modes of governance for non-human animal territories does not presently exist in any of the forms discussed this is unavoidable to some extent. The key point is that this difference in an animal trusteeship or protectorate from human ones is not something that distorts the concept to a point where it starts to lose meaning or become unrecognisable. Neither is there any normative impact in such a difference. A permanent state of paternalistic governance of this sort would be a concern in the case of human communities, but, since arguments against paternalism invariably revolve around trade-offs between protecting the welfare of a person and respecting their autonomy, there can be no trade-off with welfare to be made in acting paternally toward animals because animals lack autonomy. As Martha Nussbaum remarks '[a]n intelligently respectful paternalism is vastly superior to neglect'. ${ }^{52}$ This makes intervention into the affairs of the non-human animals for humanitarian purposes such as in the case of disease, starvation, invasion, or natural disaster far less problematic than in the case of human political communities. Nevertheless, some principles governing intervention are still needed. Donaldson and Kymlicka outline some criteria for legitimate intervention based upon the principle (mirroring justifications in the humanitarian arena) that intervention should either not interfere with sovereignty, such as in small scale acts of compassion to save individual animals in dire need, or should be undertaken with the explicit goal of restoring sovereignty. ${ }^{53}$ As principles justifying intervention in fully sovereign territories I find little to disagree with in these proposals; sovereignty has never been an absolute concept and it is increasingly being recast to place it at the service of those encompassed by it. The principle of protecting citizens from crimes against humanity is, to quote Meernik, 'a more privileged norm than sovereignty in some circumstances. ${ }^{, 54}$

\footnotetext{
${ }^{52}$ Nussbaum, Frontiers of Justice, 370. Just as respectful paternalism is not only not only unproblematic, but also necessary in human communities such as where severely cognitively impaired humans are represented and looked-after by legal guardians.

${ }^{53}$ Donaldson and Kymlicka, Zoopolis: A Political Theory of Animal Rights, 180-182.

${ }^{54}$ James Meernik, 'Reaching Inside the State: International Law and Superior Liability', International Studies Perspectives 5, no. 4 (November 2004): 356.
} 
Indeed, at the World Summit 2005 states came together to agree that there is a state 'duty to protect' that allows sovereignty to be overridden where gross human rights violations are occurring. ${ }^{55}$ The same is true of cases where aid is needed due to disaster. There is therefore no conceptual reason why similar principles could not apply to animal protectorates or trusteeships in cases of natural disaster, invasion, disease and so forth. ${ }^{56}$ Indeed, as I have mentioned, the normative case for nonintervention in the affairs of sovereign bodies is increasingly founded on respect for a political community's autonomy and right to self-determination. Nussbaum argues that this requirement for respectful treatment expressed through non-intervention kicks in when a 'nation is above a certain threshold in terms of democratic legitimacy. ${ }^{57}$ In the case of non-human animals, arguments against such intervention are weaker because there is no 'respect for autonomy' or 'selfdetermination' hurdle to overcome. A more paternalistic version of the responsibility to protect principle of the United Nations, which focuses upon protecting their interests, would thus be permissible for wild animal territories.

\section{Conclusions}

It is clear that some animals have sufficiently strong interests in their habitats to generate rights to that habitat. Although habitat rights need not be instantiated through legal rights, the evidence suggests that current systems of habitat protection are failing. Property rights offer stronger protections for non-human animals than existing models of environmental stewardship, but they need to be accompanied by means for addressing non-compliance in order to be meaningful. This requires political and legal structures to include means for non-human animals to have their interests represented, both at the domestic and international level. Where serious and systematic violations of the habitat rights of wild animals occur, secession under international management

\footnotetext{
${ }^{55}$ R. Riddell, Does Foreign Aid Really Work? (Oxford: Oxford University Press, 2007), 328.

${ }^{56} \mathrm{Cf}$. Hadley, 'The Duty to Aid Nonhuman Animals in Dire Need'.

${ }^{57}$ Nussbaum, Frontiers of Justice, 258.
} 
may be the only means to adequately protect habitats, with international bodies acting not solely in the interests of human beings, but also in the interests of other sentient beings. Ownership and secession need not always require the exclusion of humans from the habitats of wild animals since the interests animals have in their habitats can be met without it. An approach to habitat protection based upon protecting the interests sentient beings have in their environment offers stronger protection than existing systems and is morally preferable to ignoring those interests on speciesist grounds. A system of rights based upon collective usufructuary property ownership in the first instance, and remedial secession and partial sovereignty rights in the second is conceptually and normatively preferable to full ownership and full sovereignty. At the same time, this configuration of habitat rights has the additional benefit of being more practically feasible than a system of sovereignty rights based upon primary secession. 


\section{Bibliography}

Barry, Brian. 'Sustainability and Intergenerational Justice'. Theoria: A Journal of Social and Political Theory, no. 89 (1997): 43-64.

Birkett, Lucy, and William McGrew. "'Unnatural Behavior” Obstacle or Insight at the Species Interface?'. In The Politics of Species: Reshaping Our Relationships with Other Animals, edited by Raymond Corbey and Annette Lanjouw. Cambridge: Cambridge University Press, 2013.

Buchanan, Allen. 'The Making and Unmaking of Boundaries: What Liberalism Has to Say'. In States Nations and Borders, edited by Allen Buchanan and Margaret Moore. Cambridge: Cambridge University Press, 2003.

Cochrane, Alasdair. Animal Rights without Liberation: Applied Ethics and Human Obligations. New York: Columbia University Press, 2012. . An Introduction to Animals and Political Theory. Hampshire: Palgrave Macmillan, 2010.

—. 'Do Animals Have an Interest in Liberty?' Political Studies 57, no. 3 (2009): 660-79.

Convention on International Trade in Endangered Species of Wild Fauna and Flora (CITES). Washington, March 3, 1973, 993 U.N.T.S. 243

DeGrazia, David. Animal Rights: A Very Short Introduction. Oxford: Oxford University Press, 2002. Donaldson, Sue, and Will Kymlicka. Zoopolis: A Political Theory of Animal Rights. Oxford: Oxford University Press, 2011.

Feinberg, Joel. 'The Rights of Animals and Unborn Generations'. In Ethical Theory: An Anthology, edited by Russ Shafer-Landau, 2 edition. Chichester, West Sussex ; Malden, MA: WileyBlackwell, 2012. 
Forthcoming in Environmental Values @The White Horse Press http://www.whpress.co.uk

Felipe Fernández-Armesto. So You Think You're Human?: A Brief History of Humankind, Oxford: Oxford University Press, 2005.

Francione, Gary L., and Robert Garner. The Animal Rights Debate: Abolition or Regulation? New York: Columbia University Press, 2010.

Garner, Robert. A Theory of Justice for Animals: Animal Rights in a Nonideal World. Oxford: Oxford University Press, 2013.

Goodin, Robert E., Carole Pateman, and Roy Pateman. 'Simian Sovereignty'. Political Theory 25, no. 6 (1 December 1997): 821-49.

Governance, Commission on Global. Our Global Neighbourhood: The Report of the Commission on Global Governance. Oxford: Oxford University Press, 1995.

Hadley, J. 'The Duty to Aid Nonhuman Animals in Dire Need'. Journal of Applied Philosophy 23, no. 4 (2006): 445-51.

Hadley, John. 'Nonhuman Animal Property: Reconciling Environmentalism and Animal Rights'. Journal of Social Philosophy 36, no. 3 (2005): 305-15.

Hayward, Tim. Constitutional Environmental Rights. Vol. 14. 4. Oxford: Oxford University Press, 2004.

Hohfeld, Wesley Newcomb. 'Fundamental Legal Conceptions as Applied in Judicial Reasoning'. The Yale Law Journal 26, no. 8 (June 1917): 710-70.

Korsgaard, Christine. 'Fellow Creatures: Kantian Ethics and Our Duties to Animals.' Tanner Lectures on Human Values, no. 24 (2004): 77-110.

Meernik, James. 'Reaching Inside the State: International Law and Superior Liability'. International Studies Perspectives 5, no. 4 (November 2004): 356-77.

Miller, David. 'Social Justice and Environmental Goods'. In Fairness and Futurity, edited by Andrew Dobson. Oxford: Oxford University Press, 1999. 
Forthcoming in Environmental Values (The White Horse Press http://www.whpress.co.uk

Milman, Oliver. 'Government-Backed Logging “Pushing Rare Possum towards Extinction”.' The Guardian, 26 May 2013, sec. Environment.

http://www.theguardian.com/environment/2013/may/26/logging-pushing-possum-towardsextinction.

Morrogh-Bernard, Helen Celia. 'Fur-Rubbing as a Form of Self-Medication in Pongo Pygmaeus'. International Journal of Primatology 29, no. 4 (18 June 2008): 1059-64.

Nine, Cara. 'Territory Is Not Derived from Property: A Response to Steiner'. Political Studies 56, no. 4 (2008): 957-63.

Norton, Bryan G. Toward Unity among Environmentalists. Oxford: Oxford University Press, 1994.

Nussbaum, Martha. Frontiers of Justice. London: The Belknap Press of Harvard University Press, 2006.

‘Orangutan Crisis - Sumatran Orangutan Society’. Accessed 4 January 2012. http://www.orangutans-sos.org/orangutans/crisis.

‘Orangutan Facts - Sumatran Orangutan Society’: Accessed 4 January 2012. http://www.orangutans-sos.org/kids/orangutan_facts.

Passmore, John. 'Attitudes to Nature'. Royal Institute of Philosophy Supplements 8 (March 1974): $251-64$.

'Pongo Abelii (Sumatran Orangutan)'. The IUCN Red List of Threatened Species. Accessed 4 January 2012. http://www.iucnredlist.org/apps/redlist/details/39780/0.

Rachels, James. 'Do Animals Have a Right to Liberty?'. In Animal Rights and Human Obligations, edited by Tom Regan and Peter Singer. London: Prentice-Hall, 1976.

Rawls, John. A Theory of Justice: Revised Edition. Cambridge, Massachusetts: Belknap Press of Harvard University Press, 1999.

Raz, Joseph. The Morality of Freedom. Oxford: Oxford University Press, 1988.

Regan, Tom. Defending Animal Rights. Champaign, IL: University of Illinois Press, 2001. 
—. The Case for Animal Rights. 2nd ed. Berkeley and Los Angeles: University of California Press, 2004.

Regan, Tom, and Carl Cohen, eds. The Animal Rights Debate. Lanham: Rowman and Littlefield, 2001.

Riddell, R. Does Foreign Aid Really Work? Oxford: Oxford University Press, 2007.

Shelton, Dinah. 'Human Rights, Environmental Rights, and the Right to Environment.' Stanford Journal of International Law 28 (1992 1991): 103.

Shue, Henry. Basic Rights. 2nd ed. Princeton: Princeton University Press, 1996.

Shumaker, Robert W. Orangutans. St. Paul, MN: Voyageur Press, 2007.

Stilz, Anna. 'Why Do States Have Territorial Rights?' International Theory 1, no. 02 (2009): 185213.

Van Schaik, Carel P., Marc Ancrenaz, Gwendolyn Borgen, Birute Galdikas, Cheryl D. Knott, Ian Singleton, Akira Suzuki, Sri Suci Utami, and Michelle Merrill. 'Orangutan Cultures and the Evolution of Material Culture.' Science 299, no. 5603 (3 January 2003): 102-5.

Waldron, Jeremy. 'A Right-Based Critique of Constitutional Rights.' Oxford Journal of Legal Studies 13, no. 1 (1 April 1993): 18-51. 